DOI 10.37882/2223-2982.2020.05.26

\title{
«ЗАПРОСЫ ПАРТИИ И КОМИНТЕРНА - ОРИЕНТИР ДЛЯ ИСТОРИКА» (О ВЗАИМОДЕЙСТВИИ НАУКИ И ПАРТИИ НА ПРИМЕРЕ ДИСКУССИИ ПО ИСТОРИИ ЗАПАДА 1931 Г.)
}

\section{"QUESTIONS OF THE PARTY AND THE COMINTERN - A GUIDANCE FOR A HISTORIAN" (ABOUT THE INTERACTION OF SCIENCE AND PARTY USING THE EXAMPLE OF DISCUSSION ON THE HISTORY OF THE WEST 1931)}

N. Pepelina

Summary: The problem of the influence of politics on historical science and its subordination to government interests was examined, using the example of a discussion that took place in Soviet scientific and party institutions in the first half of 1931 and was devoted to studying Western European history.

Keywords: Western history, Marxist historians, discussion, ideology, Communist International, International Leninist School.
Пепелина Наталья Игоревна

К.и.н., дочент, ФГБОУ ВО «Московская государственная академия ветеринарной медицины и биотехнологии -

МВА им. К.И. Скрябина» referatpep@yandex.ru

Аннотация: На примере дискуссии, которая проходила в советских научных и партийных учреждениях в первой половине 1931 г. и была посвящена вопросам изучения западно-европейской истории, рассмотрена проблема влияния политики на историческую науку, подчинение ее правительственным интересам.

Ключевые слова: история Запада, историки-марксисты, дискуссия, идеология, Коммунистический Интернационал, Международная ленинская школа.
Д искуссия - неотъемлемая часть исторического познания, ведущая к постижению истины. Различные концепции, гипотезы и подходы, часто осмыслить изучаемый материал и найти верный путь решения научной проблемы. Диспуты сопровождают исторические исследования постоянно, но не всегда их ведение остается в рамках строгого научного спора. Отчасти подобное связано с тем, что история - дисциплина, которая испытывает значительное идеологическое влияние и в определённой степени зависит от политической ситуации в государстве. Это в первую очередь сказывается на содержании исторического образования, так как возникает необходимость решать задачи патриотического воспитания граждан, готовых поддерживать и отстаивать линию партии и правительства, а при необходимости сражаться за нее. Но и академическая наука, поставленная на службу государства, имеет перед собой такие же цели. Известны периоды, когда соответствие ее содержания интересам стоящих у власти политиков носило ультимативный обязательный характер. Причем подобное положение не отменяло существования собственно полемики в исследовательской среде. Но их ход и результаты приобретали далекий от научного поиска характер.

Такой была дискуссия «на западном участке истори- ческого фронта», проходившая в Москве в первой половине 1931 года. Цели ее проведения, споры, которые она вызвала, особенности аргументации, своеобразие отношений между ее участниками - все это продемонстрировало специфику ситуации, сложившейся в советской исторической науке к этому времени, отразило степень влияние политики страны и ее задач на историческую науку, подчиненность последней интересам государства и его руководителей, показало особый уровень взаимодействия партии и науки.

Конец 1920-х - начало 1930-х годов во внутренней политике СССР ознаменован масштабными социальноэкономическими преобразованиями. В 1928 году принят первый пятилетний план, взяты курсы на индустриализацию и коллективизацию. Во внешней политике Советскому государству было необходимо обеспечить безопасность страны для проведения запланированной реконструкции народного хозяйства, создать надежные Вооруженные силы, способные противостоять внешней угрозе. Перечисленные обстоятельства требовали огромных человеческих ресурсов, поэтому добиться успеха в начинаниях оказалось невозможно без максимальной гражданской поддержки со стороны населения, его веры в справедливость происходящего, в правоту партии и ее лидеров, несмотря на все сопутствующие трудности, лишения и тяготы, сопровождавшие 
советских людей на этом пути.

Выбранная единая линия управления государством предполагала отсутствие разногласий как в правящих кругах ${ }^{1}$, так и среди населения. Для становления некоего концептуального идеологического единства сознания масс активно привлекались ученые-историки, которые могли преподнести политически значимые события в том свете, который отвечал задачам власти. Нужно было полностью искоренить все элементы «враждебной ленинизму идеологии», под которой понимались левый и правый уклоны, работа «буржуазных» историков, и т.п., т.е. всех, кто не поддерживал генеральную линию ВКП(б). «Суть истории в том, как неоднократно говорилось, что это самая политическая из всех наук, и ее увязка теории с практикой заключается в том, что история должна непосредственно и неустанно разъяснять массам происходящую классовую борьбу...» $[8$, с.5].

Ориентиры в теоретической работе для советских историков прозвучали в отчетном докладе И.В. Сталина на XVI съезде ВKП(б): «наша работа по социалистической реконструкции народного хозяйства, рвущая экономические связи капитализма... не может не вызывать отчаянного сопротивления со стороны этих сил... Надо иметь в виду то обстоятельство..., что вокруг СССР имеются враждебные классовые силы, готовые поддержать наших классовых врагов внутри СССР...... Но ... чтобы подавить сопротивления врагов и преодолеть трудности, для этого существует одно средство: организовать наступление на капиталистические элементы по всему фронту и изолировать оппортунистические элементы в наших рядах, мешающие наступлению... и вносящие в партию неуверенность в победе» [15, с. 302-305].

В условиях противостояния СССР империалистическому миру особую роль в организации и распространении революционных идей и движений играл Коммунистический Интернационал, который проводил «мобилизацию широких пролетарских сил» для подготовки предполагаемого скорого краха капиталистической системы и свершения революций. В своем выступлении на XVI съезде ВКП(б) В.С. Молотов назвал социал-демократические партии главной опорой «империалистической буржуазии в рабочем классе», идущей «по пути фашистского перерождения» и сформулировал задачи Коминтерна: «для роста компартий и для укрепления их влияния в массах важнейшее значение имеет проблема создания руководящих кадров.... в некоторых секциях Коминтерна даже руководящее ядро компартий в значительной степени состояло из явно оппортунистических правых элементов. Поэтому в отчетный период происходило не только коренное обновление руководящего состава ряда секций Коминтерна, но и прямое изгнание из его рядов целой группы руководителей отдельных компартий» [6, с. 416]. На VI Конгрессе Коминтерна в 1928 г. были приняты решения, направленные на продолжение курса централизации руководства коммунистическим движением и соблюдение строгой международной партийной дисциплины, расширение полномочий ИККИ², отразившие тем самым усиление контроля за Коминтерном со стороны ВКП(б) [1, с. 137].

Для обучения среднего и высшего кадрового состава иностранных коммунистических партий в 1926 году в Москве была открыта Международная ленинская школа (МЛШ) $)^{3}$ «Фактически эта интернациональная школа функционировала при Президиуме ИККИ и его отделе агитации и пропаганды» [14, с. 155]. Первые четыре года школу возглавлял Н. И. Бухарин. В результате внутриполитической борьбы он был снят с должности директора МЛШ. Сменила его на этом посту К.И. Кирсанова 4 . «В 1920-1930-е гг. в МЛШ в качестве разовых лекторов часто приглашали руководящих работников большевистской партии и Коминтерна. Преподавателей подбирали отделы агитации и пропаганды ЦК ВКП(б) и ИККИ, прежде всего из Коммунистического университета им. Я.М. Свердлова и Института красной профессуры. Некоторые преподаватели занимали руководящие посты в школе» [14, с. 174]. Понятно, что содержание образования в МЛШ полностью соответствовало политическим интересам Коминтерна и ВКП(б).

Политический момент и задачи правительства, поставленные в различного рода докладах и резолюциях (в том числе, в решениях конференции аграрниковмарксистов на фоне речи Сталина, в отчетном докладе на XVI съезде ВKП(б)), нашли отражение в работе историков-марксистов. Среди первоочередных целей можно выделить: закрепление линии партии во внутренней и внешней политике, обоснование ее верности и необходимости, разработка исторических вопросов, подходящая их интерпретации 5 .

Так, с конца 1920-х годов в историческом сообществе началась борьба с «буржуазными» историками, которые

\footnotetext{
Этим, в том числе, можно объяснить столь жесткий характер политической борьбы в конце 1920-х - 1930-х гг. Исполнительный Комитет Коммунистического Интернационала

Международная ленинская школа прекратила свое существование в 1938 г.

Кирсанова Клавдия Ивановна, 1887-1947, член РСДРП с 1904 г., жена Ем. Ярославского

Например, тезисы фракции Совета Общества историков-марксистов «О задачах марксистской исторической науки в реконструктивный период», принятые ею 6 февраля 1931 года; одноименная статья М. Н. Покровского. Нетрудно заметить, что в качестве основополагающих документов задействованы доклад И.В. Сталина на 16 съезде ВКП(б) и некоторые другие его выступления.
} 
подверглись череде критики, увольнений, отстранений от дел, а по отношению к некоторым - арестов. Кроме того, советские историки нового поколения видели свое предназначение не только в исследовании проблем, неизученных ранее, но и в переработке многих тем, нашедших отражение в трудах дореволюционных ученых. Партийность исторической науки была объявлена главной ее чертой: «просто продолжать «буржуазную» науку не может и не должен ни один марксист. Мы должны брать темы, наиболее тесно связанные с той борьбой, в которой мы являемся участниками» $[7$, с. 11], - прозвучало в Обществе историков-марксистов в начале 1931 г. Например, «давно пора приняться за детальное изучение Германской революции 1918-1923 годов, чего еще ни один историк-марксист нашей страны не делал» [7, с. 15], тем более, что «ленинское понимание западной истории до сих пор систематически изучено не было» [7, с.16]. Важнейшая задача советских историков-западников - рассматривать историю как «оружие классовой борьбы». Выступая в Обществе историков-марксистов, ведущий советский историк М.Н. Покровский говорил о том, что партийность исторической науки обусловлена не только и не столько продолжением «буржуазной» науки, но выбором новых тем, закрытых до революции. Одной из этих тем он называл как раз современную историю Запа- да, которая оказалась недостаточно проработана с точки зрения ленинизма «в истории и борьба с его противниками на всем историческом фронте. Эта пропаганда должна быть теснейшим образом увязана с текущей работой партии и Коминтерна, которым нужны «грамотные историки»» [7, с.16]. Идея о тесной взаимосвязи партии и исторической науки, постановке последней на службу интересов ВКП(б), составила основной посыл рассматриваемой дискуссии.

Дискуссия «на западном участке исторического фронта» проводилась ${ }^{6}$ в партийных организациях и исследовательских учреждениях, организованных советской властью, между историками-марксистами, в основном воспитанниками семинаров М.Н. Покровского. Ключевыми участниками стали «красный профессор» М.Н. Покровский и крупные специалисты по западноевропейской истории - Н.М. Лукин ${ }^{7}$ и Г.С. Фридлянд ${ }^{8}$, с одной стороны, и представители Коминтерна - партийные деятели, с другой.

Доклады по дискуссии звучали в Институте Красной профессуры ${ }^{9}$, Институте истории Коммунистической Академии ${ }^{10}$, Обществе историков-марксистов ${ }^{11}$, Институте Маркса-Энгельса ${ }^{12}$, Истпарте ${ }^{13}$ и Международной

6 Дискуссия началась в феврале и закончилась в мае-июне 1931 г., хотя вызванные ею личные споры продолжались и далее, причем они звучали уже как политические обвинения и разбирательства

7 Лукин Николай Михайлович, 1885 - 1940. Советский историк-марксист. С 1929 г. академик АН СССР. Основные труды посвящены истории Франц. революции XVIII века, Парижской коммуны 1871 года, международного рабочего движения. В 1925 году один из основателей Общества историков-марксистов. В 1920-х - начале 1930-х годов преподавал также в Академии Генштаба, в Институте красной профессуры. В 1930-1934 годы профессор, заведующий кафедрой истории эпохи империа-лизма историко-философского факультета, в 1934-1938 годы заведующий кафедрой истории Новей-шего времени исторического факультета МГУ. В 1932-1936 годы директор Института истории Ком-мунистической академии. В 1936-1938 годы директор Института истории АН СССР. В 1933-1938 годы ответственный редактор журнала «Историк-марксист». Арестован в августе 1938 года, умер в заключении.

8 Фридлянд Григорий Самойлович 1897 - 1937. Советский историк-марксист. Специалист по истории Великой французской революции, профессор. В 1934 г. стал первым деканом восстановленного исторического факультета МГУ. В 1936 г. арестован, расстрелян.

9 Институт Красной профессуры - в РСФСР и СССР высшее учебное заведение для подготовки преподавателей - марксистов по общественным наукам и партийных работников. Существовал с 1921 по 1938 гг. в 1921 - 1932 гг. ректор ИКП - М.Н. Покровский

10 Коммунистическая академия - высшее учебное заведение, а также научно-исследовательское учреждение РСФСР и СССР. Включала научные институты, в том числе, истории. Существовала с 1918 по 1936 гг. Председатель академии - М.Н. Покровский

11 Общество историков-марксистов - организация, действовавшая в 1925-1936 годах. Было создано по инициативе М. Н. Покровского при Комакадемии для объединения советских историков. Основные задачи общества - сплочение марксистских кадров для проведения исследовательской работы в области истории и методологии исторического процесса, борьбы с буржуазной идеологией, популяризации исторических знаний и достижений советской науки. Среди учредителей были М. Н. Покровский, А. В. Шестаков, В. П. Волгин, П. О. Горин, А. М. Панкратова и др. В 1932 - 33 прекратило своё существование.

12 Институт Маркса - Энгельса - в рамках Комакадемии в 1920 году был создан Музей марксизма, преобразованный в 1921 г. в научно-исследовательский Институт Маркса и Энгельса, который существовал сначала как автономное учреждение при Социалистической академии (Коммунистической), а с 1 июня 1922 года стал самостоятельным учреждением при ВЦИК РСФСР (с апреля 1924 года — при ЦИК СССР). В 1931 года решением Президиума ЦИК СССР Институт Ленина был объединен с Институтом К. Маркса и Ф. Энгельса, создан Институт Маркса - Энгельса — Ленина при ЦК ВКП(б) (ИМЭЛ), который просуществовал до 1991 г.

13 Истпарт - Комиссия по истории Октябрьской революции и Коммунистической партии - научно-пропагандистская организация в РСФСР и СССР, занималась сбором, систематизацией, изучением, пропагандой и публикацией материалов по истории партии большевиков и революции, орган партийного руководства исторической наукой. Существовала с 1920. В 1928 произошло объединение с Институтом В.И. Ленина. 
ленинской школе, ИККИ. В дальнейшем к участию были привлечены Культпроп ${ }^{14}$, ячейка ВКП(б) ${ }^{15}$, райком партии, и некоторые другие партийные учреждения, задействованные уже в большей степени для выяснения персональных споров между некоторыми участниками дискуссии.

Причинами дискуссии явились, во-первых, необходимость разработки единой системы взглядов на роль и сущность социал-демократических партий на Западе; во-вторых, неразработанность вопросов и проблем современной европейской истории - революций и революционного движения, рабочего движения; в-третьих, отсутствие истории Коминтерна. Актуальной была потребность создать «подлинную марксистскую концепцию истории германской социал-демократии, учитывающую все этапы ее эволюции» [5. С. 59]. Все это оказалось важно для решения политических задач, перечисленных выше и сводящихся, в числе прочего, к разработке твердо выдержанной идеологической линии, отражающей официально принятую историческую концепцию, созданную в интересах существующего государственного строя и с учетом внутреннего и внешнего политического моментов.

Дискуссия началась с публикации и обсуждения резолюции «Положение и задачи западно-исторического научного фронта» «За решительный поворот!», подготовленной на кафедре по истории рабочего международного движения и Коминтерна Международной ленинской школы и принятой единогласно на заседании кафедры 13.02.1931 г. [9, л. 1]. Лейтмотивом документа звучала мысль о том, что историческая наука и трудившиеся на ее поприще ученые должны обслуживать политические интересы партийных организаций, в первую очередь Коминтерна (в соответствии с родом деятельности МЛш и состава ее студентов - представителей коммунистических партий зарубежных стран). Советские историки, которые должны были активно заниматься вопросами, значимыми для МЛШ (такими как, например, международное рабочее и революционное движение), с задачей, по мнению представителей Коминтерна, не справлялись $[9, \text { л. } 1]^{16}$. Им вменялось в вину «наличие резкого несоответствия между состоянием исторической науки вообще, ее западного участка в частности и особенности, с одной стороны и теми задачами, которые поставила партия перед историками-коммунистами, с другой» [9, л. 2]. Участники дискуссии по истории стран Запада, еще вче- ра громившие буржуазных историков за их идеологическую и научную несостоятельность, сами стали объектом идеологической проработки [13, с. 188]. От историковмарксистов в кратчайшие сроки требовалось «пронизывание всей исторической науки марксистско-ленинской методологией и большевистской партийностью.... Наши братские компартии не имеют возможности в процессе революционной борьбы глубоко изучать и теоретически обобщать свой революционный опыт» [9, л. 14]. От ученых ждали предоставление Коминтерну необходимого разработанного исторического материала. «Историческое знание - острое политическое оружие в руках практиков международной пролетарской революции» $[9$, л. 19] - говорилось в резолюции, и сделать его таковым должны были историки-марксисты.

На фоне поставленных целей Международная ленинская школа в силу своей специфики «может и должна стать базой разработки важнейших актуальных проблем послевоенного революционного движения, базой, на которой может быть осуществлена подлинная связь ленинской теории с многообразной практикой борьбы рабочего класса и его партий в различных странах» [9, л. 20].

Один из историков-марксистов, подвергшийся критике в резолюции МЛШ, Г.С. Фридлянд не согласился с выдвинутыми против него обвинениями, и дискуссия перешла в личный конфликт ученого и некоторых сотрудников МЛШ. Стороны, стремясь доказать свою правоту, обращались в партийные организации и лично к возглавлявшим эти организации лицам ${ }^{17}$

В марте вышло Постановление ЦК ВКП(б) о работе Коммунистической академии, в котором опять прозвучали слова о необходимости научным работникам сосредоточить внимание и силы на «теоретической разработке проблем социалистического строительства и классовой борьбы пролетариата» [10, с.3]. Непосредственно о дискуссии «на Западном фронте» в постановлении не сказано. Вопроса о ней коснулся глава Культпропа А. Стецкий в докладе, прочитанном в Комакадемии в конце месяца. Кроме общих положений, он отметил недопустимость излишней самокритики (на которой настаивали работники МЛШ в своих резолюциях): «отдельные товарищи выступали с такого рода положениями, что там на фронте западной истории у нас политическое неблагополучие, что неправильна генеральная

14 Отдел культуры и пропаганды ЦК ВКП(б) 1930-1934 гг. Заведующий А.И. Стецкий.

15 Ячейка ВКП(б) - первичная организация в ВКП (б) в 1919 - 1934 гг. Создавались на предприятиях, в учреждениях, воинских частях, с 1924 года сёлах. Ячейки сёл входили в уездные, городские или районные (в городах) организации, ячейки сёл в волостные и районные (с 1929 гг. - в районные) организации. Управлялась общим собранием, бюро и организатором (с 1926 г. - секретарём). В 1934 году переименованы в первичные организации.

16 Критике в первую очередь подверглись видные представители советской исторической науки (Г.С. Фридлянд, Н.М. Лукин и др.)

17 Так, например, Г.С. Фридлянд писал обращение к А.И. Стецкому - заведующему Кульпропа. 
линия работы О-ва историков-марксистов и т.д. и т.п., что необходимо поставить вопрос о руководстве этим самым фронтом западной истории и т.д. Пытались зачеркнуть все то ценное, что было сделано на этом фронте западной истории. Совершенно естественно, что таким перехлестываниям необходимо давать самый решительный отпор» $[16$, с. 16].

Конфликт на этом не закончился, противостояние между Фридляндом и МЛШ продолжалось. Стороны направляли письма в различные партийные организации Москвы, добиваясь признания собственной точки зрения. 23 июня 1931 г. состоялось заседание Бюро ячейки ВКП(б) ИКП по Истории, на котором позиция Г.С. Фридлянда была осуждена. Бюро ячейки посчитало, что «заявление т. Фридлянда свидетельствует о том, что т. Фридлянд на деле противодействует повороту на историческом фронте и мешает консолидации сил на принципиальной основе» $[2$, л. 1]. Иначе стали воспринимать дискуссии сами участники: они представлялись многим «не столько научной лабораторией по совершенствованию марксистской исторической мысли, сколько орудием борьбы с вражеской идеологией» [13, с. 188].

Сама же дискуссия окончилась летом 1931 г., когда были опубликованы доклад Лукина по итогам дискуссии и резолюция Комакадемии по тому же вопросу. Ученый повторил установки, звучавшие в выступлениях Сталина, многочисленных резолюциях и постановлениях, отметив, что «дискуссия на западном участке исторического фронта должна была конкретизировать эти общие директивы партии и Коминтерна применительно к особым задачам историков-марксистов» [3, с. 5]. В очередной раз были названы трудности, которые испытывала советская историческая наука в вопросах изучения Запада (проблематика, буржуазные историки, неразработанность многих вопросов, вредители, борьба). Решая задачи, поставленные перед учеными-марксистами партией и Коминтерном, в результате проведенной дискуссии, как отмечал Н.М. Лукин, наметились «те боевые вопросы, которые должны встать в центре внимания западников»: в первую очередь, вопросы послевоенной истории революционного движения капиталистических стран, история Коминтерна и входящих в него партий, колониальный вопрос, проблемы фашизма и социал-демократии, история империалистической войны [3, с. 7]. Еще раз были перечислены ошибки, допущенные историкамимарксистами в некоторых вопросах изучения истории Запада. Вывод звучал следующим образом: «историки Запада, которые должны исходить из переключения своей работы в помощь Коминтерну, естественно обязаны в первую очередь ясно формулировать конкретные задачи, вытекающие из этой установки, и практической помощью братским компартиям в их подготовке к решающим боям должны показать, как наиболее политическая партийная наука выполняет перед пролетариатом свои задачи» [3, с. 9].

В подобном духе выдержана Резолюция Президиума Комакадемии о положении и задачах на фронте истории Запада. Перечислены вскрытые в результате дискуссии положительные и отрицательные стороны процесса изучения истории Запада. Среди серьезных минусов отмечены недостаток бдительности в работе, а также названы ошибочные положения в работах советских историков: упомянуты фамилии и Фридляна, и Лукина, и ряда других историков-марксистов, раскритикованных представителями МлШ в ходе дискуссии. «В своей дальнейшей научно-исследовательской и популяризаторской работе историки Запада должны перенести центр тяжести на историю военной и послевоенной эпохи, выдвигая на первый план разработку актуальных проблем, связанных с текущими задачами партии и Коминтерна; историческая наука должна превратиться в остро отточенное оружие политической борьбы» [11, с. 50].

Подводя итоги, можно сказать, что линия партии в данном вопросе одержала победу, история была поставлена на службу политики - дискуссия по истории Запада тому яркая иллюстрация. Утверждение интересов ВКП(б) в исторической науке было важно и для формирования массового сознания, (в этом она использовалась как дополнительный рычаг идеологического воздействия на советское население), и в преддверии работы над едиными учебниками по истории для школ и вузов. Особая безапелляционность в вопросах исторической проблематики новейшей истории была объяснима опять же ее политической актуальностью, отсюда особое внимание к ней партийных деятелей.

\section{ЛИТЕРАТУРА}

1. Адибеков Г.М., Шахназарова Э.Н., Шириня К.К. Организационная структура Коминтерна 1919-1943 гг. М., 1997. - 287 с.

2. Выписка из протокола заседания Бюро ячейки ВКП(б) ИКП по Истории от 23.06.1931г. // ГЦМСИР. Документальный фонд, фонд Ем. Ярославского, ВС 5136/12.

3. Лукин Н.М. За большивистскую партийность в исторической науке. К итогам дискуссии на западном участке исторического фронта // Историк-марксист. М., 1931. № 22. С. 3

4. Мануильский Д.З. Лицом к боевым задачам Коминтерна // Борьба классов. М., 1931. № 2. С. 1

5. Метель 0.В. Дискуссия «на западном участке исторического фронта» и развитие советской историографии в 1920-1930-е гг. // Вестник Томского государ- 
ственного университета. История. Томск, 2018. № 53. С. 59

6. Молотов В.М. Отчет делегации ВКП(б) в ИККИ на XVI съезде ВКП(б) / XVI съезд Всесоюзной коммунистической партии (6). Стенографический отчет. М Л., 1930. -786 c.

7. 0 задачах марксистской исторической науки в реконструктивный период. Тезисы фракции Совета Общества историков-марксистов // Историк-марксист. М., 1931. № 21. С. 8

8. Покровский М.Н. 0 задачах марксистской исторической науки в реконструктивный период. // Историк-марксист. М., 1931. № 21. С. 3

9. Положение и задачи западно-исторического научного фронта. Резолюция кафедры по истории международного рабочего движения и Коминтерна Международной ленинской школы. // ГЦМСИР, Документальный фонд, фонд Ем. Ярославского, ГИК 39491/106-39.

10. Постановление ЦК ВКП(б) от 15.03.1931 г. по докладу Президиума Коммунистической академии // Вестник Коммунистической академии. М., 1931. № 2-3. С. 3

11. Резолюция Президиума Комакадемии о положении и задачах на фронте истории Запада // Вестник Коммунистической академии. М., 1931. № 8-9. С. 47

12. Сахаров А.Н. Дискуссии в советской историографии: убитая душа науки / Советская историография. М., 1996. - 592 с.

13. Соколов В.Ю. История и политика (К вопросу о содержании и характере дискуссий советских историков 1920-х - начала 1930-х гг.). Томск, 1990. - 204 с.

14. Спичак Д.А. История подготовки кадров Китайской компартии и Гоминьдана в московских учебных центрах Коминтерна: уели, методы, результаты (1921-1939 гг.) / Диссертация на соискание ученой степени кандидата исторических наук. М., 2010. - 261 с.

15. Сталин И.В. Политический отчет ЦК XVI съезду ВКП(б). 27 июня 1930 г. / Сочинения. Т. 12. М., 1949.

16. Стецкий А.И. О Комакадемии и научной работе // Вестник Коммунистической академии. М., 1931. № 2-3. С. 6

( Пепелина Наталья Игоревна (referatpep@yandex.ru).

Журнал «Современная наука: актуальные проблемы теории и практики»

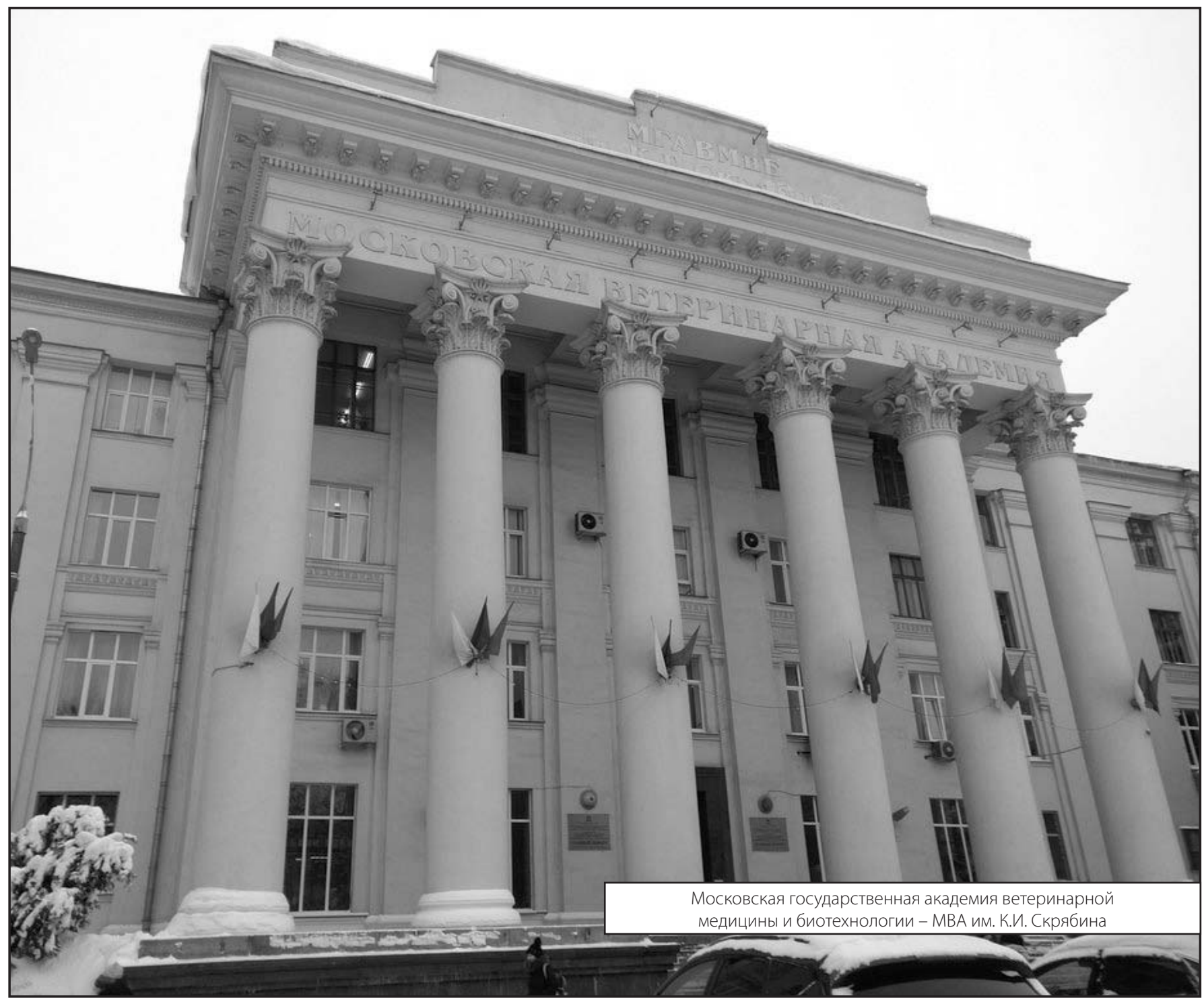

